\title{
Transitivity and youth violence in \#EndSARS discourse
}

\author{
Ifeyinwa David-0jukwu1' Florence 0. Orabueze ${ }^{2}$ \& \\ Stella Okoye-Ugwu² \\ University of Nigeria, Nsukka, \\ 'The Use of English Unit, School of General Studies. \\ ${ }^{2}$ Department of English \& Literary Studies.
}

\begin{abstract}
Violence in Nigeria has reached its peak such that policies that should engage the youths positively are inevitable. This paper aims to establish that Nigerian youths should not be held accountable for \#EndSARS protest. Using Halliday and Matthiessen's Transitivity model, the paper examined the transitivity processes of the major participants in the discourse, and the circumstances implicated. Explication of images appropriated as discursive strategies were accounted for through insights from Kress and van Leeuwen's Compositional Metafunction in Reading Image Theory. The analysis was done using a descriptive qualitative research design that supports the description of processes attributed to participants, and how social predictors that assign agentive roles to some participants as Actor, or Sayer; and strip others of their agencies suggest that in the Nigeria's social context, the \#EndSARS protest was inevitable. Such approach was critical in exposing the undercurrents that informed the protest, which previous researches had paid insignificant attention to. From the analysis, several discoveries were recorded, namely: Nigerian government is majorly, a Sayer interested mainly in protecting its pride, the police, and the military are the Actors, while the youths are the Goal in material
\end{abstract}


processes, and behaver in behavioural processes. The paper concludes that the volatility of the youths was a reaction to the processes of the government, and its agencies. The paper, therefore, recommends that government should show practical interest in the plight of the masses by initiating policies that target to engage them constructively so as to prevent future reoccurrence.

Keywords: Discourse analysis, Transitivity, Social semiotics, Nigerian government, Nigerian youth and \#EndSARS protests.

\section{Introduction}

The main thrusts of this paper are to identify the major participants in the \#EndSARS discourse; examine the transitivity processes that represent their respective experiences; explain the circumstances that are associated with the processes; and finally, establish that the transitivity processes of the protesting youths are the effect of the processes of government, and its agencies, which undermine the dignity of the Nigerian youths. Previous studies on \#EndSARS protest had examined it from sociological perspectives (egs. Dambo, et al 2020; Obogo 2020; Akinpelu 2021) and historical (eg. Orabueze, et al 2021). These researches had interrogated the causes of \#EndSARS protest without significant efforts made to examine the interface between language, and the incidences of the \#EndSARS protest.

Thus, the psychological undercurrents that precipitated the protest, which represent the Nigerian youths as irresponsible are critical discursive segments of the protest that were undermined in previous researches. The youths are the major stakeholder in any society, and so understudying the incidence that pitches them against the government is imperative in articulating future policies that will forestall a re-occurrence of violence that had been noted among researchers to be the end-product of protest. Examining language use in the \#EndSARS discourse to identify the participants, processes, and circumstances is indispensable in establishing the truism that the Nigerian 
youths should not be held responsible for the destruction of lives, and properties that trailed the protest. The present paper is meant to fill this gap.

Violence among Nigerian youths has become a global concern, and endemic to the Nigerian state. It is a social stigma that should be a concern to every well meaning Nigerian citizen. Violence results in destruction of lives and properties. In Nigeria's social context, it has created a gulf between the government and the people, thereby, undermining the rapport that should exist between the ruler and the ruled. Ukaogo (2009) thus, laments that violence is a "festering sore" (p. 054) that constructs negative image of the Nigerian state. This worrisome situation has bedeviled the country for decades, and has elicited huge interest among researchers. Thus, several analytical models had been deployed to interrogate, among other things, social, economic and political factors that incubate, and exacerbate violence among the youths.

These extant studies, examples, Ukaogo (2009); Echezona et a (2011); Ebekue (2017); Aborishade and Adedayo (2018); etc. agree that violence in Nigeria is a representation of the angst, poverty, unemployment, disillusionment, serial killings, marginalisation, humiliation, subjugation, neglect and brutality which form the experiences of the teeming youths. Aborishade and Adedayo (2018); Collier and Joefflier (2005) claim that action, or (and) inactions of the ruling class determine the reaction of the governed.

In other words, the youths who should occupy the centre stage in governance are so impoverished that resorting to protest and violence (in reaction to oppressive systems mounted by successive government to keep them perpetually subjugated), appear enticing, and so, they exploit such approach as the only option at their disposal, thereby submitting to Collier and Joefflier (2005) that protest is driven by two contrastive forces of cause and opportunities; that while a small fraction of protest is cause-motivated, a larger chunk is opportunity-driven with the aim to loot, destroy and maim. Opportunity thrives due to poverty. These nuances, condemnable perhaps, and which construct Nigerian youths as irresponsible, and volatile, are processes that represent them as behavers in Halliday and Matthiessen (2004) behavioural transitivity processes. Such processes are the effects of physical, concrete, or, and verbal actions meted on them by the ruling class. 
The processes of those in authority could be appreciated from the Hobesian law of stratification, which promotes class disparity between "the ruler and the ruled, bourgeoisie and proletariat, the man and woman" (Ebekue p. 85). Thus, Nigerian government manipulates political structures to oppress and strangulate the populace. Protest and violence become inevitable tools exploited by the ruled to sustain what Hobesian law calls class struggle for supremacy. This was demonstrated in 2020 \#EndSARS protests in Nigeria, in which the youths deployed protest as a semiotic resource not only to communicate their dissatisfaction with the government that has failed them, but also to communicate disapproval towards the continued existence of the Special Anti-Robbery Squad (SARS), which was a special unit of the Nigeria Police Force (NPF).

Diverse semiotic resources, such as words, body postures, facial expressions, gestures, gaze, images, photographs, graphics, colours, font sizes, etc. are communicative artifacts for meaning-making (Theo van Leeuwen, 2005; Kress and van Leeuwen, 2006; Chandler, 2007; Tan and Chae 2015). Reports from both main stream and social media indicate that these semiotic resources were exploited in the \#EndSARS discourse.
Semiotic

resources

perform

representational, interactional, and compositional metafunctions, and are available in every clause (Kress and van Leeuwen 1996; 2006). A clause is a constitution of images, photographs, facial expressions, body postures, etc, represented, not only through words, but, through gestures and images. Thus, we found the ideas of social semiotics propounded by Kress and van Leeuwen 1996; 2006 appropriate to complement the transitivity theory advanced in Halliday and Matthiessen (2004) in accounting for the use of multimodal artifacts in the representation of the ugly experiences of the youth, but which government decided to undermine. Thus, wanton destruction of lives and properties became inevitable.

Kress and van Leeuwen posit that just like language, images could also be used to represent ideologies, experiences, and construct identities; negotiate different social relationships, as well as compose these experiences, and relationships as texts. They further state that the society that uses these resources assigns meanings to them through its conventions and appropriations.

Conventions are the agreed codes that govern the use of any semiotic sign: what 
is allowed, and what is not, while Literature review appropriations are the resources that are adopted from other cultures. They further explicate that it is the primary duty of the analyst to retrieve these semiotic resources and assign meanings to them. This is what the researchers are poised to accomplish in this paper.

Ibukun and Melafa (2014) utilised frameworks from social semiotics to argue that the act of nicknaming among the undergraduates of the University of Ibadan (UI) is a semiotic resource for personality re-invention. They discover that individuals that assign nicknames to themselves do so to re-construct their personalities, which their given names had shrouded. Ibukun and Melefa imply that Kress and van Leeuwen's Reading Images (1996; 2006) could account for the use of multiple communicative resources in discourse. Although, the thrust of this paper is the application of Halliday and Matthiessen (2004) in the analyses of language use in the representation of major participants, their processes, and the circumstances associated with the processes, ideas from Kress and van Leeuwen's Reading Images (1996; 2004) could be utilised where it is imperative to do so.

\section{Predictors of youth violence in Nigeria}

From empirical studies, youth violence is a product of bad and insensitive governance. Its origin in Nigeria is traced to the bastardisation of the country's economy from several years of successive military regime; the aftermath of the 1966-1970 Biafra-Nigeria war which created opportunities for the youths to possess arms and ammunitions (Echezona et al, 2011); failed federalism, and aborted resource control (Ukaogo 2009). The youths, between the ages of 18 and 50 were conscripted into the Biafran army, and very many recruited in the military and police, and because of the urgency of their service, were not properly trained. Consequently, after the war, several arms were still in their possessions. This, therefore, made it possible to resort to violence easily. True federalism would have empowered the states to control their respective natural endowments, distribute their resources to the grassroots. Thus, more jobs would have been created, infrastructures and social amenities enhanced, thereby, engaging the youth positively.

In the present Nigerian state, the resources are generated from the states, siphoned to Abuja, leaving the producing 
states impoverished. This situation runs contrary to what is obtainable in an egalitarian society where every citizen should enjoy equal rights and privileges, but, not in Nigeria where the ruling class designs policies to keep a section of the society in perpetual subjugation and oppression.

Thus, Ebekue (2017) claims that the quest for the strong to continue to subjugate the weak is what is at play in Nigeria's social context; to suggest that the world's largest black nation is indeed a microcosm of Hobesian state that stratifies a society into two unequal strata. In that instance, the oppressed, which must not be defeated in the clash of supremacy, appropriates every resource at their disposal to engage the ruling class. Appropriation is the adoption of a part, or whole of another culture as a norm in one's culture. The Nigerian youths deploy protest in post war national, ethnic and communal crises to communicate their disapproval on any issue they find unacceptable (Ukaogo 2009; Echezona, et al 2011). One vital instrument that facilitates such protest is language.

\section{Aetiology of \#Endsars protest}

At the outset of the peaceful protest, the protesters stated unequivocally, the reasons for the protest, which were to end SARS. Tanko (2020) reporting for the
British Broadcasting Corporation (BBC) stated that the protesters had explicitly itemized their demands, which must be met before they retreat, and further stated that the warning signs were ignored, which resulted in the prolonged protests. Akinpelu (2021) equally noted that the protests were ill-managed by the government at various levels which later metamorphosed into violence. Akinpelu argued that the speech made by the president was belated, as well as insensitive, and undermined the shooting, and killing of innocent protesters by the men of the armed forces. Thus, the rampage, and wanton destruction of properties by the angry youths became inevitable.

In his \#EndSARS speech, it was obvious that President Mohammadu Buhari (PMB) was not in touch with the nuances of protest as a semiotic resource otherwise, he would not have blamed the international community for escalating the protest through what he perceived as biased coverage. Blaming foreigners over Nigeria's issues has been the hallmark of the post-colonial federal government, which Orabueze, et al (2021) had previously interrogated. Orabueze, et al argued that the Nigeria's problems that precipitated the \#EndSARS protests should not be blamed on foreigners, claiming that blame game has always been the antecedents of Nigeria's 
government in lieu of meeting the Equally, Dambo, et al (2020) examined the expectations of the teeming Nigerian interface between social media and youths who are marginalised in a country that they should be the major stakeholder. Orabueze et al employed a historical critical lens to bring to the fore, instances of social malaises which characterise the government from one regime to another, and which have always been heaped on the shoulders of foreign countries like Britain, United States of America (USA), China, etc. They conclude that issues that were articulated in the protest could lead to another civil war, if unattended to.

Similarly, Obogo (2020) examined the effects of the \#EndSARS protests on the 2023 general election in the country, and found that the protest is a smear on the integrity of the present administration, and that there is a wide distance between President Buhari's campaign promises, which won him the mandate in 2015, and the actualisation of the promises, as his administration is marred by neglect, corruption, conflicts, tribalism, sectionalism, abuse of human rights by the military, NPF, and other security agencies. Thus, Obogo noted that these are the social factors that informed the \#EndSARS protests, which corroborate with Orabueze, et al that the issues that birthed \#EndSARS protests were internally motivated.

information dissemination with respect to police brutality, and he discovered that Twitter handle plays pivotal role in connecting the Nigerian youths worldwide to \#EndSARS protests, which resulted in the protests happening simultaneously both within and outside the country.

These researches, although, different from the present study, in several ways (in theories and approaches adopted), they are, however, of immense significance to the stance of this paper that the government at various levels have failed the Nigerian youths with impunity. These researches form the bases to establish that the transitivity processes of the protesting youths which construct them as behaver, in behavioural processes, are only responses to the concrete actions of the leadership class.

\section{Theory and method}

\section{Transitivity}

The theory of transitivity is a component of Halliday's Systemic Functional Linguistics (1985) in which he posits that all the activities that form man's experiences in life are represented in six processes: Material, Mental, Relational, Verbal, Behavioural and Existential 
(Halliday and Matthienssen 2004, p.269). Thompson (2004) explicates that the material processes represent man's physical and concrete actions; mental processes are processes of cognition, thinking, perception, feeling, and emotion; speaking actions belong to verbal processes; actions that represent the existence of something or somebody, as well as the processes that establish a relation between two disparate entities are the existential, and relational processes, respectively; while the behavioural processes are processes of human physiological and psychological behaviour. Thompson implies that the behavioural processes construct the participant, the behaver as responding to the effect of the concrete or verbal actions of an Actor in a material process, or a Sayer in a verbal process. Based on these explications, this paper focuses on only the material, verbal and behavioural processes for the analysis of the participants in the \#EndSARS protests discourse; the processes they engage; and the circumstances that are associated with the processes. The justification is that they are the processes that could account for the nexus between poor governance and youth volatility. Also, they are the processes that are fundamental in establishing power relationship, the use or, unuse of agentive roles to subjugate the co-participant in a discourse.

Instances of material processes are such that describe physical and concrete actions like, kick, run, paint, take, eat, give, send, kill, beat, slap, hit, knock, etc, and the main participants are the Actor who does the action, and the Goal who receives the action; Verbal processes implicate three participants: the Sayer, the participant doing the saying, the Receiver, the one being said to, and the Verbiage, what is being said about; while Behavioural processes have only a participant, the human behaver. Circumstances associated with all the processes are depicted in the why, how and where, of incidents, representing the social, political and economic issues that affect the participants, and the processes implicated.

Transitivity theory is effective in understudying the meaning that underlie the happenings in society with regards to finding answers to, who is doing what?; to whom?; what is being done?, and what are the circumstances that enhance such actions? Iwamoto (2008) explains that transitivity theory is effective in understanding who wields more power in a relationship. In a research he conducted from a story in a magazine, Iwamoto notes 
that the male participant, Stefen de vaux is depicted mainly, as an Actor in a goaldirected material processes, while his female counterpart, Claire is represented with processes that depict her as Goal.

Agbo, et al (2019) employed Halliday's (1985) Transitivity Theory to dissect President Muhammadu Buhari's (2015) campaign speeches. Their study was a quantitative analysis of the frequency counts of the processes of transitivity so as to interrogate the processes that are exploited in conveying his ideologies, which are shrouded in the grammar of the clause. The results of their work show an overwhelming use of material processes because it is the process through which he had to represent his ideologies of change, which the country was in dire need of. How far the change mantra has taken the country, politically, economically, and financially, is an issue that future researches should interrogate.

\section{Research design}

Descriptive qualitative research design was engaged in the analysis of the clauses purposively sampled from selected \#EndSARS discourses as reported in some online media, namely: BBC, CNN, and Pulse. These media were chosen because of their reputation for unbiased news coverage. Qualitative research design is fundamentally concerned with phenomenological analysis aimed at finding the meaning attributed to such a phenomenon. In the context of the present paper, the processes of the transitivity that represent the participants as actor, sayer, and behaver were discussed to determine the nexus between participant's roles, and the violence that trailed the protests. This approach is germane in under-covering the social predictors of the protests in determining the participant that were culpable in the violence that followed.

\section{Method of data collection}

A corpus of five clausal groups was, thus, extracted from different online newspapers covering the period of the protests between October 4 and October 292020 in Nigeria. For the present research, a purposive sampling method of data collection was adopted in that it is the method that affords the researcher the opportunity to sample data based on specific purposes, and encourages the description of phenomena in discourse. Thus, the researchers are concerned with why the observed resources exist, as well as their social functions.

O'Halloran (2004) avers that data for analysis constitutes every sign that signifies, including images, words, body 
postures, facial expressions, gestures, etc. Although the \#EndSARS protests discourse constitutes several semiotic resources engaged by the protesting youths to demand an end to SARS, and bad governance, the analysis was concerned with clauses expressed through verbalised language, from the perspective of Halliday's and Matthiessen's Transitivity theory (2004). However, where indispensable in explaining the incorporation of images in the protest, ideas from social semiotic frameworks were engaged for the explication of the meanings relayed in the transitivity processes. The selected clauses were presented in bold. Information in square brackets were added by the researchers to aid the identification, and explanation of the processes, participants, and circumstances.

\section{Data presentation and analysis}

Clause 1: On Monday 12th October [circumstance], I [Sayer] acknowledged [Verbal Process] the genuine concerns and agitations [Behavioural Process] of members of the public [Verbiage] regarding the excessive use of force [Material Process] by some members of SARS [Actor] [Verbiage].

Clause 2: The choice to demonstrate [behavioural process] peacefully [circumstance] is a fundamental right of citizens [behaver] as enshrined in Section
40 of our Constitution and other enactments; but this right to protest [behavioural process] also imposes [Behavioural process] on the demonstrators [Behaver] the responsibility to respect [behavioural process] the rights of other citizens, and the necessity to operate [behavioural process] within the law.

In the circumstances, [circumstance] I [senser] would like [mental process] to appeal [senser] to protesters [behaver] to note [Mental Process] and take [Mental Process] advantage of the various wellthought-out [mental process] initiatives [phenomenon] of this administration [senser] designed [material process] to make [Material Process] their lives [Goal] better and more meaningful, and resist [Mental Process] the temptation of being used [Goal] by some subversive elements [Actor] to cause [Material Process] chaos [target] with the aim of truncating [Material Process] our nascent democracy [Goal]. For you to do [material process] otherwise will amount to undermining [Behavioural Process] national security and the law and order situation. Under no circumstances will this [Behavioural Process] be tolerated. [Verbiage] (Extracts of President Buhari's \#EndSARS Speech) in Wahab (2020, Pulse online newspaper

In clause 1 , the speech of the president shows an overwhelming use of Verbal Processes to identify with the cause of the protest, and recognizing that the public 
has rights to protest over their perceived police brutality. His verbiage implicates three major participants: the president, the police and members of the public. The police are represented in his speech as the Actor, the public, as the Goal implicitly stated, but, explicitly as Behavers, while the president is the Sayer. Thus: "The genuine concerns and agitations [Behavioural Process] of members of the public [Behaver] regarding the excessive use of force [Material Process] by some members of SARS" [Actor] shows that the president is aware of police brutality against members of the public. Protest, as earlier suggested in this paper is a semiotic resource that implicates a wide space between the leaders and the led, meaning that there are issues that need to be addressed by those at the corridors of power, but which they have demonstrated attitude of indifference.

In the second paragraph of clause 1, PMB uses material process "designed" to reinforce his administration's existing plans to alleviate the suffering of the masses, and immediately swerves to mental processes to elicit emotions and sympathy from the public to agree with Halliday and Matthiessen that mental process is engaged to express emotion. The president acknowledges the nexus between government's neglect and protest when he tasked the protesters to access his government's funds that had been instituted to avoid an opportunity like the present protest occurring. However, Eranga (2020) notes that such incentives are politicised such that only a small percentage of the populace are accounted for. In other words, the deployment of mental processes to talk about the incentives suggests that the information lacks force of integrity. Agbo et al (2019) volunteer that material process is often employed when the president wants to inform the country about his achievements, and also his future plans for the citizenry; Iwamoto (2007) observes that mental process is used mostly in informal discourse in that it represents most often failed agencies. By implication, the above discourse shows that there are no serious plans in force to support the teeming Nigerian youths.

Paragraph three of the same clause reveals that PMB has initiated pre-determined plans to quash any protest occurring at any time (eg. "Under no circumstances will this be tolerated"). Thus, the shooting that characterise the \#EndSARS protests was evident to prove that the administration lacks proactive policies to manage conflicts.

Theo van Leeuwen (2005) implies that protest is a mode of communication in which the participants exploit different 
multimodal resources to express their demands inscribed in them as in the grievances. The use of protest constitutes images depicted below: the deployment of placards, with their

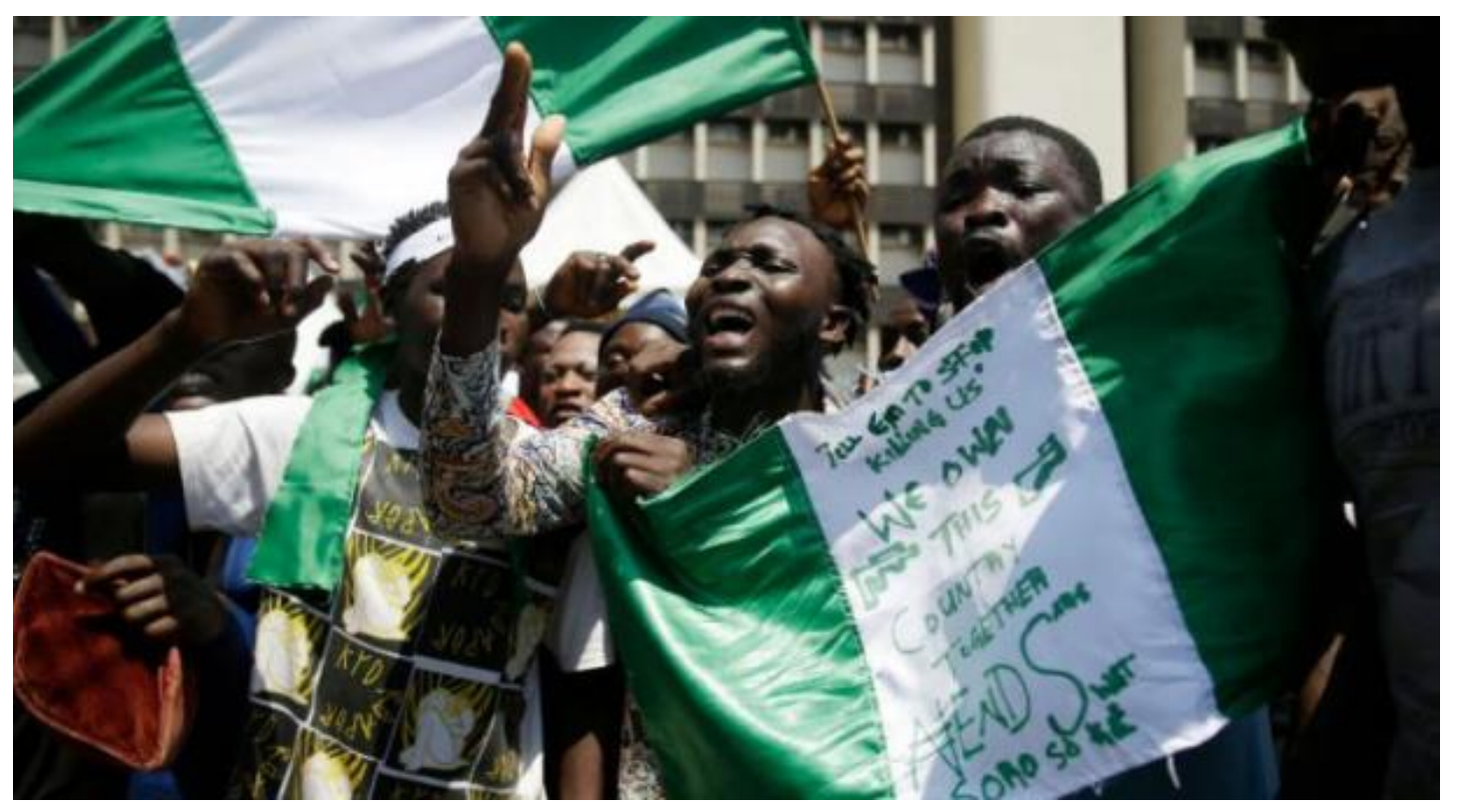

Image: Stephanie Busari, CNN (2020)

The semiotic resources implicated in the image above are the Nigerian flag of green and white colour. The protesters equally use green marker to write their demand thus:

TELL EM TO STOP KILLING US. WE OWN = THIS = COUNTRY TOGETHER \#ENDSARS ${ }_{\text {WAT }}$ SORO SOKE

Kress and van Leeuwen (1996; 2006) argue that colour saturation, uppercase, and big font sizes are semiotic strategies for framing experiences to indicate its saliency, and dependent on the value which the interactive participant, or sign producer attaches to the information. In Nigeria's socio-cultural landscape, green colour symbolizes life, vitality, fruitfulness, etc. By engaging the country's flag, the youths believe that they are fighting for the soul of Nigeria, which the political elitist class is strangulating. Their choice of green colour suggests identity with the nation's ideology. The use of green colour, with the text written in upper case is a framing strategy to foreground their belief that they are also major stakeholder in the 
country's polity, and should not be acerbated, or wished away.

Equally from the text above, two participants are involved, namely: 'them' (SARS) and 'us' (the youth). "TELL [Verbal Process] EM [Actor] TO STOP KILLING [Material Process] US [Goal] WE OWN = THIS = COUNTRY TOGETHER \#ENDSARS ${ }_{\text {WAT }}$ SORO SOKE". The protesters are expressing their fundamental rights to freedom from oppression and discrimination. The discourse shows that the men of SARS are the Actor in goal-directed material processes, while the youths are the Goal, hence, the cause of the protest in the first place. The youths can no longer keep quiet while their lives are snuffed out of them, and so they task themselves to "SORO SOKE", a Yoruba verbal phrase which Busari (2020) explains to denotatively mean "speak up" (https://edition.cnn.com/2020/10/25/afric a/nigeria-end-sars-protests-analysisintl/index.html).

Connotatively, it suggests that the protesters are coming with the understanding that the governments are not concerned with their plight, and that they have construed their hitherto quietness to mean weakness and contentment. They are also suggesting that those at the corridors of power will not do anything to meet their demands unless the whole world hears their lamentations and tales of woes, just like the Igbo proverbial hen that says that her purpose of crying is not for her captor to free her, but for the whole world to hear her. But, the Nigerian protesters need to scream to alert the international community of police brutality which has been going unabated for years, and which the presidency seems to be comfortable with.

Clause 3: Nigerian governor urges [Verbal Process] calm as witnesses [Sayer] say [Verbal Process] soldiers [Actor] fired [Material Process] on protesters [Goal] (Stephanie Busari 2020, reporting for CNN).

In clause 3 above, the four participants implicated are 'Nigerian governor', 'witnesses', 'soldiers' and 'protesters', but they have imbalance utilisation of their agencies. The SARS use the full weight of their agencies, including the butt of their guns, to override their captives, the masses, while their Goals have their agencies stripped off completely that they are at the mercy of the police. The Nigerian governor is suing for peace at the time when the protest had already gone violent after the Lekki Toll Gate massacre. Such verbiage represents the governor as 
a very insensitive and unproactive administrator who by virtue of his position would have prevented the protest from escalating.

The irresponsible attitudes of the government represented by the participant, "Nigerian governor" is not strange to the viewer as such has been their hallmarks; what the viewer is not familiar with is the shooting of the youths in peaceful demonstrations. Such material process (fired) constructs the military as untrained, and inexperienced in civil matters, meaning that their operational scope should have been limited to the barracks, and the borders, guarding the country's lands, sea and aerial territories. Kress and van Leeuwen (1996) further argue that information value is realised through framing; in this clause, "fired" is used as framing strategy to heighten the agentive role of the actor (the military) against their hapless goal (the protesters).

Clause 4: For nearly two weeks [Circumstance] angry young Nigerians [Behavers] have taken [Behavioural Process] to the streets [Circumstance] blocking [Material Process] major roads [Goal] across cities in Africa's most populous nation [Circumstance] (Stephanie Busari, CNN, 2020)
The circumstance in clause 4 above means that the protest has taken two weeks already, and yet, the country's president had not deemed it fit to address the protesters who had engaged multimodal resources to express their grievances. "Angry young Nigerians" and "major roads" are the only participants in the clause 4 and they are represented as Behavers in Behavioural Process, such as "have taken", and Actor in Material process "blocking". Their processes are not directly targeted at any human participant.

Rather, as Kress and van Leeuwen (2006) explain, the protesters are reactors in a reactional non-transactional narrative process whose actions are not directed at the goal. This means that their processes are only to elicit attention from government to accept their demand, to scrap SARS for its brutality. The protesters' Behavioural Processes construct them as people who have lost their sense of dignity, and undermine their humanness. Hence, they engage all manner of resources to express their emotions by obstructing free movement of traffic.

Clause 5: "One body [behaver] from the toll gate [circumstance] showed [behavioural process] signs of blunt force trauma. A second body [goal] from 
another location in Lagos State be their primary duty. It is thus, obvious [circumstance] had bullet wounds. The that they were deployed to "shoot" the government [sayer] acknowledged [verbal process] that soldiers [actor] armed [material process] with live ammunition were present at the Lekki Toll Gate [circumstance]. At year's end [circumstance] the Lagos State Judicial Panel of Inquiry and Restitution [senser] continued to hear [mental] testimony and investigate [material process] the shooting [material process] at Lekki Toll Gate [circumstance]," the report [sayer] noted [verbal process]. (Blinken, 2021, U.S. Secretary of State) in Akinpelu (2021)

Clause 5 above constitutes six major participants: "one body, a second body, government, soldiers armed with live ammunition, Lagos state judicial panel of inquiry and restitution and the public who continue to give testimonies". All of these participants construct different processes of transitivity as illustrated (see Image 2).

From the analysis in clause 5, the Nigerian "soldiers" is represented as the Actor in a goal-directed Material Process, who shot and killed some of the protesters at the Lekki Toll Gate. It is an aberration that soldiers whose fundamental duty is to defend the country should be involved with civil cases that were not supposed to protesters for violating the curfew order imposed by the Lagos state government. Their Goals, the nameless "one body" and "the second body" indicate not only that they are already dead, but that they could not be identified.

In the Nigeria's socio-cultural clime, every human being has at least three names: first, middle and last; excluding

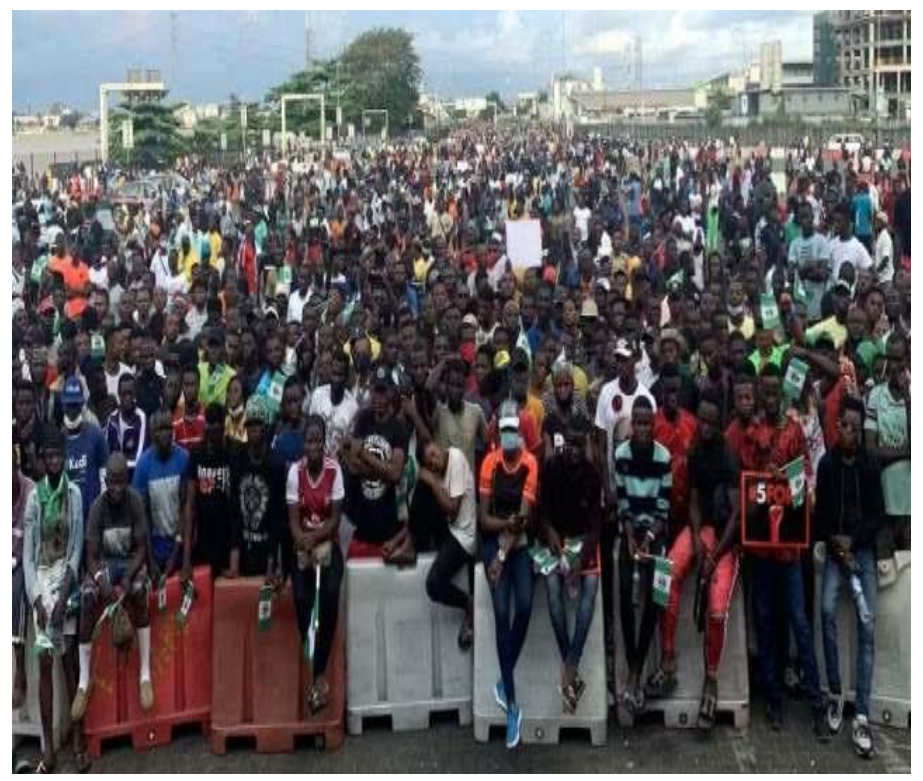

Image 2 Blinken, 2020, Twitter handle)

nick names, which scholars like lbukun and Melefa (2014) claim are semiotic resources for re-construction of identities. Therefore, by the Goals being unnamed implicates the dearth of databases of Nigeria's citizens which makes it 
inevitably difficult to account for the government that they are ready for interest of the different classes of the dialogue.

populace.

Moreover, from the protesters depicted in the photograph (Blinken, 2021) below, it is obvious that they engaged semiotic resources of placards; calmly composed body postures without any form of violence to represent their position that the government should scrap SARS. Theo Van Leeuwen (2005); Kress and van Leeuwen (2006); Tan and Chae (2015) and Nordquish (2020) agree that body postures, a kind of kinesics, are resources for meaning making. In African cosmology, sitting down suggests that the participant is interested in interaction. Hence, a person who sits in a stool ('oche okpoga' among the Igbo people of Southeast, Nigeria) connotes patience, which means that the sitting interlocutor is interested in interaction.

Also, a workaholic person often receives reprimands for not sitting down to rest; just as a woman does not appreciate her husband if he cannot sit down and interact with her. Therefore, a participant that sits down is beckoning on the other to join in the discourse. The \#EndSARS protests equally appropriates sitting down posture as a semiotic resource to show the

There is an imaginary vector coming from the eye contacts of the protesters which connects them to their target interlocutor, the government. Thus, as Kress and van Leeuwen further explain, such interaction is transactional narrative process, which would have resulted in social relations between the two disparate participants. Social relation is the kind of relationship that exists among colleagues in offices, and also between participants of unequal statuses, such as teacher and student, health worker and patient, lawyer and client. Hall (1966) explains that its spatial dimension is between four and twelve feet, and it is used for small group interactions such as sitting around a dinner with others, or a group meeting.

The youths constitute major segment of any society, and so the relationship that should exist between them and those at the corridors of power should be social. This view was exemplified in the peaceful protests which the \#EndSARS connotes initially, before it went bloody after the Lekki shooting.

The circumstance of the protest, "At Lekki Toll Gate", one of Lagos's centres of 
attraction shows that the protesters aimed to draw the attention of the government faster. By "blocking" the high profile Lagos traffic, the protesters are represented through Behavioural Process as behaving out of the ordinary.

\section{Discussion}

The results of the analysis in this paper have shown an overwhelming use of verbal processes by the federal government, and Lagos state government; material processes by SARS; soldiers and behavioural processes by the protesting youths. The verbal processes represent the governments as Sayer, who used the power of language to intimidate the protesting youths as shown in PMB's warning that "...Under no circumstances will this be tolerated" (Wahab 2020). The warning was contained in the \#EndSARS speech delivered by the president two days after the Lekki sporadic shooting by the Nigerian soldiers.

The verbal processes of the president show that his interest was not that the youths were killed, but that the ego, reputation, and image of his administration were undermined. By his transitivity processes, he demonstrated his disinterest, astute neglect, and sheer disrespect to the fundamental rights of the protesters to exploit the resource of protest to communicate their disapproval of police extra-judicial killings, extortion, rape, which characterise his administration. Thus, his transitivity processes expose his unwillingness to address such satanic evils, and invariably means that there is no end to brutality.

Equally, state government is represented through verbal processes, thus: "Nigerian governor urges calm as witnesses say soldiers fired on protesters" (Stephanie 2020) shows that they too are detached from the plight of the youths. To "urge calm" after scores of youths who were peacefully sitting at the Lekki Toll Gate had been shot by the soldiers was only demonstration of hypocrisy, and their passion to maneuver the masses through the power of language. "Urges calm" in the circumstance it was used, is noncommittal, thereby resulting in the violence that followed the Lekki shooting.

The Lagos State Judicial Panel of Inquiry and Restitution is another participant implicated in the discourse whose transitivity processes are not in any way better than its principals. It is represented as an actor in a goal-directed material process, with Lekki shooting, as its Goal. As an Actor, it is supposed to engage its agency to investigate the participant culpable in the shooting, but, by "continued to investigate" suggests that the panel is non-functional. "Continued" 
shows that the investigation has no end, and so, is a make-belief panel.

Likewise, the SARS is another major participant shown to deploy material processes to effect concrete oppressive actions against the youth. For instance, "armed", "shooting", "killed", "excessive use of force", etc. are processes of brutality, which SARS were known for. The antecedents of SARS had been going unabated for years, yet, the powers that be had allowed such to continue until the youths had to exploit the resources of protest to demand an end to such bastardly incidences.

Another group of participant in the \#EndSARS discourse is the Nigerian soldiers. They are represented as Actor in a goal-directed material process: "soldiers armed with live ammunition...", which shows that soldiers were culpable in the killing of a good number of people during the protest. This is evidenced by the circumstance of the process: "at Lekki Toll Gate" implicates the location of the shooting. Lamentably, the photographs of the youth depicted in the image at the toll gate before the shooting represents the youth as peaceful, harmless, and devoid of any violence. What any well-meaning government should have done was to engage the protesters in a dialogue that would have articulated their demands, and aspirations, which the government owes the responsibility to perform.

Conversely, the protesters are shown to use behavioural processes, such as: "angry" (Nigerian youths); "have taken" (to the streets); "blocking" (major roads); etc. to represent their grievances towards the insensitivity of the federal and state governments, to their plight. To "take to the streets" construct a very poor image of the Nigerian youths, which represent them as people who have lost their mental balance. "Blocking major roads" further represent their state of near insanity in that these are antecedents that characterise a participant's state of insanity. By their behavioural processes, the youths are manifesting the effects of the verbal, and material processes of the governments, and the NPF as the only resource deemed effective to advance their stance against any form of oppression, subjugation, and marginalisation.

It is also shown that prior to the behavioural processes of the youth, the 'Nigerian masses' are the goal in a goaldirected material processes, which implicate men of NPF, and Nigerian 
soldiers as the Actor, as in "One body from youth as behaver in behavioural the toll gate showed signs of blunt force transitivity processes, it is stating the trauma." "A second body from another obvious that the youths employed protest location in Lagos State had bullet to express their frustration. Their wounds." It was, therefore, in response to processes undermine their human dignity, the material processes of the participants and so genuine efforts should be advanced culpable in the shooting of the to rehabilitate, and take them away from participants that resulted in the violent the streets by creating employment actions of the youth. opportunities for them, instead of condemning them to the gallows. By so

\section{Conclusion}

Having established that the actions of the youth which represent them as behaver in behavioural transitivity processes follow the oppressive actions of the NPF, and the doing, future protests will be averted. We, equally, recommend that government should initiate policies that encourage periodic training of security operatives on better ways to manage protests. 


\section{References}

Aborisade, R. A. Adedayo, S. S. (2018). Social media and youth violence in Nigeria: A psychosocial review. Journal Identifiers, Vol. 26 No. 2 (2018) eISSN: 1117-1421 https://www.ajol.info/index.php/ifep/article/view/178795.

Agbo, I. I., Ngwoke, F. U. \& ljem, B. U. (2019). Transitivity processes in president buhari's 'my covenant with Nigerians. English Language Teaching, Vol. 12 No.4 pp.7-14.

Akinpelu, Y. (2021). "Lekki Tollgate Shooting: U.S. yet to confirm number of people killed Report". https://www.premiumtimesng.com/news/headlines/452510-lekki-tollgateshooting-u-s-yet-to-confirm-number-of-people-killed-report.html

Busari, S. (2020). "Nigeria's youth finds its voice with the EndSARS protest movement" https://www.edition.cnn.com/2020/10/25/africa/nigeria-end-sars-protests-analysisintl/index.html.

Collier, Paul. Sambanis, N. (2005). Understanding civil war: Evidence and analysis, Vol. 2. Europe, Central Asia, and Other Regions. Washington, DC: World Bank. ${ }^{\odot}$ World Bank. https://openknowledge.worldbank.org/handle/10986/7438 License: CC BY 3.0 IG0.

Chandler, D. (2007). Semiotics: the basics. $2^{\text {nd }}$ Edition. London: Routledge.

Dambo, T. H., Ersoy, M., Auwal, A. M., Olorunsola, V. O. Olonode, A., Abdulgaffar Olawale Arikewuyo, A. 0. \& Joseph, A. (2020). "Nigeria's \#EndSARS movement and its implication on online protests in Africa's most populous country https://www.researchgate.net/publication/347330172_Nigeria\%27s_EndSARS_movement_and _its_implication_on_online_protests_in_Africa\%27s_most_populous_country

Ebekue, E. O. (2017). Intra-Gender Subjugation among Women in Nigeria: A Study of Stephanie Okere's Dry. Creative Artist Vol. 11, pp. 84-102

Echezona, R. I., Ugwu, C. I. \& Ozioko, R. E. (2011). Socio-economic predictors of youth violence in Nigeria: Library intervention strategies. Journal of Applied Information Science and Technology, Vol. 5.1. pp. 66-72. https://www.jaistonline.org

Eranga, I. O. (2020). COVID-19 Pandemic in Nigeria: Palliative Measures and the Politics of Vulnerability. Int J MCH AIDS, 9 (2), pp. 220-222. PMID: 32685279, doi: 10.21106/ijma.394, https://www.ncbi.nIm.nih.gov/pmc/articles/PMC7359756/

George, A. (2020). "The roots of the \#EndSARS protests in Nigeria". 
https://www.washingtonpost.com/outlook/2020/10/25/roots-endsars-protests-nigeria/

Hall, E. T. (1966). The hidden dimension. New York: Doubleday.

Halliday, M. A. K. \& Matthiessen, M. I. M. (2004). An introduction to functional grammar. 3rd ed. London: Hodder Education <www.human.kanagawau.ac.jp/gakkai/publ/pdf/no 162/16209.pdf, New- York: Palgrave, pp. 181-204.

Halliday, M. A. K. (1978). Language as social semiotic: The social interpretation of language and meaning, London: Edward Arnold.

Ibukun, F. \& Melefa, O. M. (2014). A Socio-semiotic study of nicknaming among undergraduates in a Nigerian university. Linguistik Online 68, 6/14, pp. 21-4. https://www.researchgate.net/publication/269403046_A_Sociosemiotic_Study_of_Nicknaming_among_Undergraduates_in_a_Nigerian_University.

Iwamoto, N. (2007). "Linguistic analysis of a literary text using Systemic Functional Grammar" https://www.semanticscholar.org/paper/Stylistic-andLinguistic-Analysis-of-a-literary- \%E5\%B2\%A9\%E6\%9C\%AC I/5f6f02cf0c446e32555c17e8cd9d59af91839bbc.

Kress, G. \& Leeuwen, T. van. (1996). Reading images: the grammar of visual design, first edition, New York: Routledge.

Kress, G. \& Leeuwen, T. van. (2006). Reading Images: The Grammar of Visual Design, Third edition. New York: Routledge

Nordquist, R. (2020). Semiotics definition and examples. https://www.thoughtco.com/semiotics-definition-1692082.

Obogo, C. (2020). "EndSARS protests and likely impact on 2023". Sun News online. https://www.sunnewsonline.com/endsars-protests-and-likely-impact-on-2023elections/

O'Halloran, K. (2004). Multimodal discourse analysis: Systemic functional perspectives, London: Continuum.

Orabueze, F. O., Ukaogo, V. O., David-Ojukwu, I., Eze, G. I. \& Orabueze, C. I. (2021). "Reminiscence on \#EndSARS protests of 2020 in Nigeria". Rupkatha Journal on Interdisciplinary Studies in Humanities (ISSN 0975-2935) DOAJ, ERIHPLUS Vol. 13, 
No.1,January-March,2021.PP.1-15,

http://rupkatha.com/V13/n1/v13n111.pdfD0I:https://dx.doi.org/10.21659/rupkatha.v13n1

Tan, H. T. \& Chae, T. K. (2015). Multimodal discourse: A visual design of two advertising images. International Journal of Contents, June 2015, DOI:

10.5392/IJoC.2015.11.2.2050,pp.50-56

https://www.researchgate.net/publication/282839711

Tanko, A. (2020). "How the \#EndSars protests have changed Nigeria forever" https://www.bbc.com/news/world-africa-54662986

Thompson, G. (2004). Introduction to Functional Grammar. 2nd Ed., London: Edward Arnold.

Ukaogo, V. O. (2009) Strangulated federalism, resource rights agitations and the deepening crisis in the Niger-Delta. African Journal of History and Culture (AJHC) Vol. 1 (3), pp. 054-059, September, http://www.academicjournals.org/AJHC

Van Leeuwen, T. (2005). Introducing social semiotics. London: Routledge.

Wahab, B. (2020). "Full text of Buhari's speech on \#ENDSARS protests". https://www.pulse.ng/news/local/full-text-of-buharis-speech-on-endsarsprotests/7dqrwf9 